Theme D: Mathematics for all: why? what? when? In C. Winsløw (ed.), Nordic research in mathematics education. Rotterdam: Sense Publishers.

\title{
LIFELONG MATHEMATICS EDUCATION (2): EMPOWER, DISEMPOWER, COUNTERPOWER?
}

\author{
Paola Valero $^{1}$ and Tine Wedege ${ }^{2}$ \\ ${ }^{1}$ Aalborg University, Denmark; ${ }^{2}$ Malmö University, Sweden
}

Theme D: Mathematics for all: why? what? when?

\section{MOTIVATION}

Mathematics education is a central part of the lifelong learning strategies in the Nordic countries. Besides economic justifications for this (see "Lifelong mathematics education (1): Needs and constraints", in this volume), one of the main arguments supporting the provision of mathematics education for all students and at all levels is connected to the idea that mathematics is a powerful resource for social action and that through the learning of mathematics citizens will acquire that powerful resource. The power of mathematics and mathematics education is clearly assumed in policy documents in educational systems, in teachers' practices, and in research in the teaching and learning of mathematics (Skovsmose \& Valero, 2002).

However, it is not clear what is really meant by the terms "power" and "mathematics" (Valero, 2006), particularly when it is being used differently by the multiple actors involved in giving meaning to the practices of the teaching and learning of mathematics in society. Furthermore, from our research we have seen that in practice the realization of whatever might be meant by the power of mathematics and mathematics education leads researchers, teachers and students to a variety of situations. Sometimes those situations may seem powerful and empowering since learners are able to participate and influence working or everyday life processes through the use of mathematical resources. However, more often than not teaching and learning situations in mathematics are rather disempowering since they lead to the complete rejection of the learners' possibilities to develop mathematical competence (Wedege, 2000). Still, it could be desirable -but it happens less often in practice- to have counterempowering situations where learners are able to question the power of mathematics and mathematics education and take a critical distance to it, its unfolding in society, and its influence on their lives (FitzSimons, 2002). In other words, the meaning of the term "power" in relation to mathematics and mathematics education deserves a more detailed examination.

\section{QUESTIONS FOR DISCUSSION}

In the second topic group on lifelong mathematics education, the two main questions below invited to providing clarification of the meaning of the term "power" in relation to mathematics and mathematics education, and to linking those meanings with their implications: 
Theme D: Mathematics for all: why? what? when? In C. Winsløw (ed.), Nordic research in mathematics education. Rotterdam: Sense Publishers.

1. Which notions of power are connected to mathematics and mathematics education?

2. What are the consequences for research and for practice of these notions of power?

\section{DEBATE}

In the session we invited participants to explore these two questions based on a short motivation for discussion where three different narratives, short stories illustrating different views and conceptions found in mathematics education practices about the power of mathematics and mathematics education. The narratives were taken from Christensen et al. (2008b). A first narrative exemplified an intrinsic perspective on the power of mathematics and mathematics education. In a classroom, we follow the thoughts of teacher and students. While the students work on a trigonometry problem the teacher is thinking about the many things he forgot at home. The students work on a problem. Ali is trying to send text messages from his mobile phone and is thinking about the party next week, while Louise, a bright student, has already finished solving the problem. The teacher looks at them and thinks about his opinions about the two students. While Louise is quite competent in mathematics -though unusual for a girl- Ali simply does not have what it takes to do maths. The narrative concludes:

"Later that summer Louise receives yet another set of top grades and decides to continue with advanced mathematics. She has a dream of becoming a medical doctor so she needs the good grades. She wants to be like her dad and continue the family tradition of going through university. Ali gets one of the lowest term grades in the class and it will only add to a number of grades that are equally low in other subjects reinforcing his experience of being incapable of learning anything. Just like his siblings and parents. This boy was born with the wrong genes...” (Christensen et al., 2008b, p. 135).

A second narrative exemplified a technological perspective on the power of mathematics and mathematics education. In a TV studio, there is a debate between the Minister of Science and Technology and the leader of the opposition party. The Minister talks about the demands of competitiveness on the qualifications of the labour force and the need for as high education as possible for all, in particular:

"We are simply scoring too low in the international tests on mathematics and science year after year. Unless we strengthen the focus on these subjects our competitiveness and ability to be in the forefront of technological advances will simply disappear." (Christensen et al., 2008b, p. 138)

A third narrative illustrated a structural inequality perspective. In the setting of a professional development course for teachers, a teacher educator and researcher is discussing with a group of school teachers on whether mathematics education 
Theme D: Mathematics for all: why? what? when? In C. Winsløw (ed.), Nordic research in mathematics education. Rotterdam: Sense Publishers.

practices can be inclusive of all students or whether mathematics education exercises the exclusion of some students. A teacher thinks:

"That's true but we always try to work with the parents in order to ensure the inclusion of the children from under-privileged homes. What else can we do?” (Christensen et al., 2008b, p. 141)

The narratives triggered different reactions on the participants. A first reaction was how these stories resonated with ideas and comments that participants in the session have frequently met in their professional lives in their countries (Norway, Sweden, France, Austria and Denmark). This observation was commented to indicate that, even though mathematics education researchers are not normally used to think in terms of power about their field of practice and research, there is a clear political dimension in it, in that in public discourse as well as in specialized professional discourse, people characterize mathematics as being powerful, in relation to its uses and applications. Concerning mathematics education, its importance is also acknowledged in relation to the education of all citizens. The question emerging was: how come there seems to be a general agreement on that matter?

The political dimension comes to be constituted in society in relation to the meaning and significance that very different people, through history, have conferred to mathematics and mathematics education. For example, the similarities among the political discourse of pleading for a better mathematics (and science) qualification of citizens as a way of maintaining the superiority of the existing economic and social order were recognized to be astonishing. This political discourse has remained, in essence, the same from the time of the Sputnik Shock in the 1960's and of the New Maths Movement. The justifications for increasing the mathematical competence of people for strengthening the Western civilization against the expansion of communism in the time of the cold war, has been replaced by the terms belonging to the informational and globalization era: competitiveness, entrepreneurship and innovation.

In other spheres, many mathematics teachers adhere to the narrative of the intrinsic power of mathematics. The example provided as a motivation for discussion was confirmed by many participants when reflecting on the fact that many mathematics teachers adhere to the idea that learning mathematics is in itself an empowering experience. However that experience seems to be reserved to few students who "have what it takes" to be able to learn mathematics properly. The discussion raised questions about this belief, and the idea that we cannot assume any intrinsic goodness in simply learning mathematics but rather we should look for the reasons why socially we ascribe a positive valorisation to being able to display mathematical tools and ways of reasoning when dealing with the world.

Finally, although many participants could think of the different meanings given to the term "power", when set in relation to mathematics and mathematics education, some 
Theme D: Mathematics for all: why? what? when? In C. Winsløw (ed.), Nordic research in mathematics education. Rotterdam: Sense Publishers.

participants were concerned with the situation where many of these discussions seem to be very value-laden and very ideological, and not as grounded in empirical research findings as it is the case of many other discussions in other branches of mathematics education research. This concern was taken as an invitation to keep on examining the political dimensions of mathematics education from a theoretical perspective, but especially to generate empirical studies in classrooms, schools, policy-making and many other instances of social practice about how people construe the power of mathematics and mathematics education. The particular examples provided by Michele Artigue about recent curricular changes in France that introduced statistics in the secondary school mathematics curriculum in a time of political elections, could be taken as one example of phenomena that could open for empirical investigations on these issues. It is our hope that these types of investigation, which have been one of the characteristic subfields of research of the Nordic mathematics education research community, can be nourished and developed further in the future, with the purpose of reminding us why is it that mathematics education occupies a privileged place in our educational systems and societies.

\section{REFERENCES}

Christensen, O. R., Stentoft, D., \& Valero, P. (2008a). A Landscape of Power Distribution. In K. Nolan \& E. De Freitas (Eds.), Opening the Research Text: Critical Insights and In(ter)ventions into Mathematics Education (pp. 147-154). New York: Springer.

Christensen, O. R., Stentoft, D., \& Valero, P. (2008b). Power Distribution in the Network of Mathematics Education Practices. In K. Nolan \& E. De Freitas (Eds.), Opening the Research Text: Critical Insights and In(ter)ventions into Mathematics Education (pp. 131-146). New York: Springer.

FitzSimons, G. E. (2002). What counts as mathematics? Technologies of power in adult and vocational education. Dordrecht: Kluwer Academic Publishers.

Valero, P. (2006). Diskurser om magt i matematikdidaktisk forskning: Begreber og handlemuligheder. In M. Blomhøj \& O. Skovsmose (Eds.), Kunne det tænkes? om matematiklæring (pp. 296-311). Albertslund (Denmark): Malling Beck.

Skovsmose, O., \& Valero, P. (2002). Democratic access to powerful mathematical ideas. In L. D. English (Ed.), Handbook of international research in mathematics education. Directions for the 21st Century. (pp. 383-407). Mahwah, NJ: Erlbaum.

Wedege, T. (2000). Technology, Competences and Mathematics. In Coben, D.; FitzSimons, G.; O’Donoghue, J. (Eds.), Perspectives on Adults Learning Mathematics: Research and Practice. (pp.192-209) Dordrecht: Kluwer Academic Publishers. 